Univerzitet u Nišu, DOI: https://doi.org/10.46630/gpsi.18.2019.10

Filozofski fakultet,

Departman za psihologiju,

Niš, Srbija

\title{
ZNAČAJ PORODIČNOG FUNKCIONISANJA I MEĐULJUDSKIH ODNOSA NA POSLU ZA DOŽIVLJAJ KONFLIKTA IZMEĐU POSLA I PORODICE ${ }^{23}$
}

\begin{abstract}
Apstrakt
Cilj ovog rada bio je utvrđivanje efekata dimenzija porodičnog funkcionisanja i odnosa sa kolegama i pretpostavljenim na doživljaj konflikta između posla i porodice kod zaposlenih osoba koje su u braku i imaju decu. Na uzorku, koji je obuhvatao 644 ispitanika oba pola (59.1\% ženskog), primenjene su odgovarajuće skale iz PORPOS baterije, konstruisane za potrebe projekta 179002, čiji je cilj bio ispitivanje diverziteta odnosa na poslu i u porodici u Srbiji 2011. godine. Za procenu dimenzija porodičnog funkcionisanja korišćene su stavke preuzete iz skala FACES III i FACES IV, dok su ostale varijable (konflikt posao-porodica i međuljudski odnosi na poslu) ispitivane skalama konstruisanim unutar navedenog projekta. Od dimenzija porodičnog funkcionisanja, samo komunikacija se izdvojila kao značajni prediktor, dok su iz domena posla, obe vrste odnosa (sa kolegama i nadređenim) predviđale doživljaj konflikta posaoporodica. Sa povećanjem procenjenog kvaliteta ovih odnosa, kao i porodične komunikacije, smanjivao se konflikt. Efekti komunikacije delom su posredovani navedenim odnosima na poslu. Što je kvalitet porodične komunikacije procenjen višim, to je bolje ocenjen i kvalitet ovih odnosa, a konflikt manjim. Uprkos niskom procentu objašnjene varijanse, dobijeni rezultati opravdali su pretpostavljeni doprinos interpersonalnih odnosa na poslu i u porodici predviđanjem usklađenosti poslovnih i porodičnih uloga.
\end{abstract}

Ključne reči: konflikt posla i porodice, porodično funkcionisanje, odnos sa kolegama, odnos sa pretpostavljenim

\section{Uvod}

Zauzimanjem određenih pozicija u društvu, osoba pristaje i na usvajanje obrazaca ponašanja koje članovi tog društva očekuju od pojedinca na tim položajima (Rot, 2008). Drugim rečima, osoba uči iz čega se sastoji njena uloga, usvajajući postepeno ove organizovane sisteme ponašanja. Međutim, osoba, u složenoj društvenoj

\footnotetext{
${ }^{1}$ Adresa autora: marija.pejicic@filfak.ni.ac.rs

${ }^{2}$ Napomena: Nastanak rada je finansiran sredstvima Ministarstva prosvete, nauke i tehnološkog razvoja Republike Srbije u okviru rada na projektu 179002.

${ }^{3}$ Rad je prezentovan na međunarodnoj naučnoj konferenciji XV Dani primenjene psihologije, Niš, Filozofski fakultet [28. septembar 2019. godine].
} 
strukturi nikada nema samo jednu funkciju, već u isto vreme teži da se ostvari u većem broju uloga. Tako, ona, na primer, može zauzimati poziciju osobe određenog pola, pripadnika određene nacije, bračnog partnera, roditelja, zaposlenog, prijatelja, itd. Obrasci ponašanja iz kojih je sastavljena svaka od ovih uloga, odnosno, zadaci koje svaki od ovih položaja zahteva, mogu biti manje ili više usklađeni. Zaposlenje žena stvorilo je u porodičnom okruženju tlo za razvoj nove vrste konflikta uloga konflikt porodičnih i poslovnih uloga (Hedrih, 2013). Dok je tradicionalna porodica podrazumevala dominaciju muškarca i jasnu raspodelu funkcija, u kojoj muškarac radi, a žena brine o deci, savremena funkcionalna porodica ima aktivan odnos prema proširivanju tih funkcija. Tako sada ove granice postaju slabije, funkcije koje muškarac i žena obavljaju u porodici i van nje se proširuju, što se ogleda u posvećivanju žena profesiji i karijeri i uključivanju muškaraca u aktivno roditeljstvo. Kako su sada oba partnera angažovana, kako na poslovnom, tako i na porodičnom planu, javlja se potreba za usklađivanjem zahteva različitih uloga.

\section{Odnos posla i porodice}

Nasuprot autorima koji smatraju da je usklađivanje poslovnih i porodičnih uloga težak zadatak za pojedinca jer se radi o dvema međusobno inkompatibilnim sferama, postoje autori prema čijem mišljenju su ove dve oblasti međusobno nezavisne (Zedeck, 1987). Međutim, prema nekim shvatanjima, moguća je i kompenzacija između ovih sfera. Kompleksnost odnosa između posla i porodice ilustruje postojanje velikog broja teorija, u kojima je on posmatran na različite načine. Neke od njih, Zedek (Zedeck, 1987) navodi u svom radu, i to su: teorija prelivanja, teorija kompenzacije, teorija segmenata, teorija instrumentalnosti, teorija konflikta i integrativna teorija.

Prema teoriji prelivanja, postoji sličnost između onoga što se dešava u poslovnom okruženju i kućnom okruženju (Zedeck, 1987). Osećanja, iskustva, stavovi koje osoba stiče na poslu imaju tendenciju da se manifestuju i u drugim oblastima njenog života. Drugim rečima, između ovih sfera ne postoje jasne granice. Prelivanja mogu biti pozitivna, pa podrazumevati, na primer, prenošenje zadovoljstva sa posla na porodicu, ali i negativna, gde stres na poslu može da se odrazi negativno na porodične odnose, zahtevajući od pojedinca korišćenje personalnih i porodičnih resursa u svrhe prevladavanja. Teorija kompenzacije se često posmatra kao suprotnost teoriji prelivanja jer podrazumeva da su porodica i posao u komplementarnom odnosu, pa pojedinac angažovanjem u jednoj sferi ostvaruje ono što u drugoj ne može. Teorija segmenata ove dve sfere života smatra međusobno nezavisnim. Zastupnici ovog stajališta smatraju da su porodica i posao razdvojeni u vremenu, prostoru i prema funkcijama, pri čemu porodica zadovoljava potrebu osobe za intimnošću i interpersonalnim razmenama, dok se poslovno okruženje smatra nepersonalnim, kompetitivnim i instrumentalnim. Zedek (Zedeck, 1987) ove tri teorije smatra dominantnim pristupima $u$ istraživanju odnosa između posla i porodice, dok preostale pomenute teorije posmatra kao njihove dopune. Prema teoriji instrumentalnosti, jedna sfera je sredstvo za ostvarivanje ciljeva u drugoj (na primer, materijalni prihodi, koje 
obezbeđuje posao, omogućavaju osobi da život van posla ispuni iskustvima koja joj pričinjavaju zadovoljstvo). Teorija konflikta pretpostavlja da su posao i porodica međusobno inkompatibilne oblasti, koje podrazumevaju različite norme i zahteve, usled čega uspeh u jednoj zahteva žrtve u drugoj sferi. Integrativna teorija ove oblasti smatra toliko povezanim, da ih je nemoguće posmatrati odvojeno jednu od druge.

Prema pregledu empirijskih podataka koje navodi Hedrih (2013), pretpostavka o konfliktu između posla i porodice se izdvaja kao opravdana, što ne isključuje mogućnost postojanja i drugačije forme interakcije između ovih oblasti. Konflikt posla i porodice se definiše kao „forma konflikta između uloga u kome su pritisci uloga iz poslovnog i porodičnog domena u izvesnom smislu međusobno inkompatibilini“، (Greenhaus \& Beutell, 1985, p. 77). Prema ovim autorima, do konflikta može da dođe ako osoba nema dovoljno vremena za obavljanje obaveza u oba domena, ili ako tenzija doživljena u jednoj oblasti ugrožava ispunjavanje zadataka u drugoj, ili onda kada posao zahteva drugačiju vrstu ponašanja, inkompatibilnu sa ponašanjem koje zahtevaju potrebe porodice. Istraživanja antecedenasa i konsekvenci ovog sukoba su ukazala na potrebu za diferencijacijom konflikta posao-porodica i konflikta porodica-posao (Netemeyer, Boles, \& McMurrian, 1996). Dok u prvom slučaju, usled posvećenosti poslovnim obavezama, trpi porodica, druga vrsta sukoba se javlja onda kada zahtevi porodice ometaju izvršavanje poslovnih zadataka.

Analizirajući rezultate istraživanja koja su se bavila efektima različitih konstrukata na doživljaj konflikta posao-porodica i konflikta porodica-posao, Bajron (Byron, 2005) je ispitivane antecedense podelio u tri grupe: 1) varijable iz oblasti posla; 2) varijable koje pripadaju sferama van posla i 3 ) individualne i demografske varijable. Oslanjanjem na ovu kategorizaciju, fokus ovog rada stavljen je na ispitivanje značaja koji bi za doživljavanje konflikata između posla i porodice mogle da imaju različite forme interpersonalnih odnosa, kako one u porodici, tako i one na poslu. Pritom, kontrolisana je uloga određenih sociodemografskih karakteristika zaposlenih na pomenute vrste konflikata.

\section{Porodično funkcionisanje}

Jedan od modela kojim je moguće prikazati različite aspekte porodičnog funkcionisanja jeste Olsonov Cirkumpleks model porodičnog funkcionisanja (Olson, 2000, 2011). Prema njemu, karakteristike porodice mogu da se sagledaju kroz tri dimenzije: kohezivnost, fleksibilnost (adaptabilnost) i komunikaciju. Kohezivnost se odnosi na stepen emocionalne povezanosti između članova porodice, pri čemu jedan pol podrazumeva zajedništvo, a drugi odvajanje. Dok se sa jedne strane nalaze ekstremno emocionalno nepovezane porodice, na drugoj strani se nalaze porodice u kojima je kohezija veoma visoka, pa su članovi međusobno visoko umreženi. Između ovih ekstrema se nalaze porodice čiji su članovi nisko do umereno povezani, odnosno umereno do visoko povezani. Prema ideji Olsona, ovi umereni nivoi kohezivnosti podrazumevaju balans između zajedništva i odvajanja, zbog čega ih treba smatrati funkcionalnijim obrascima, u poređenju sa ekstremnom odvojenošću ili povezanošću članova. Porodična fleksibilnost, odnosno adaptabilnost se definiše 
kao „kvalitet i ekspresija vođstva i organizacije, odnosa između uloga, pravila u odnosu i pregovaranja“" (Oslon, 2011, str. 65). Tako se porodice mogu razlikovati prema tome u kom stepenu njeni članovi pokazuju spremnost i sposobnost da menjaju strukturu moći, odnose između uloga i pravila u svojim odnosima kako bi se porodica razvijala. Funkcionalnim porodicama se smatraju one koje su uspostavile balans između stabilnosti i promena u svom sistemu. Na ovoj dimenziji, porodice se kreću od onih rigidnih (u kojima je fleksibilnost niska) do onih ekstremno fleksibilnih, koje podrazumevaju haotičnost. Između ovih ekstrema se nalaze strukturisane i fleksibilne porodice, koje Olson (Olson, 2000) smatra balansiranim, te stoga funkcionalnim. Komunikacija je treća dimenzija, koja se smatra važnom za definisanje funkcionalnosti porodica uzimajući u obzir prethodno opisane dimenzije. Drugim rečima, ona omogućava uspostavljanje balansiranih pozicija na dimenzijama kohezivnosti i fleksibilnosti. Porodice se mogu razlikovati prema stepenu razvijenosti veština slušanja svojih članova, pri čemu je fokus na empatiji i pažljivom slušanju. Pored razvijene veštine slušanja, u funkcionalnim sistemima članovi govore za sebe, ne u ime drugih, pokazuju spremnost na otvaranje i deljenje osećanja. Osim toga, funkcionalne porodice karakteriše i zadržavanje na temi o kojoj se razgovara, uz međusobno uvažavanje i poštovanje, što je važno za pružanje podrške i efikasno rešavanje problema. Dakle, funkcionalnim porodicama se smatraju one u kojima su navedene komunikacione veštine visoko razvijene.

Za ispitivanje ovih dimenzija konstruisano je nekoliko verzija instrumenta FACES (Family Adaptability \& Cohesion Evaluation Scales). Neke od verzija (FACES II (Olson, Portner, \& Bell, 1982) i FACES III (Olson, Portner, \& Lavee, 1985)) jesu „linearni” instrumenti ili sadrže „linearne“ skale FACES IV (Olson, 2011), što znači da visoki skorovi na navedenim dimenzijama govore o većoj funkcionalnosti porodice. Tako je utvrđeno da fleksibilnost i kohezivnost jesu u linearnom odnosu sa pozitivnim ishodima (npr. Boyraz \& Sayger, 2011; Farrell \& Barnes, 1993; Vandeleur, Perrez, \& Schoebi, 2007). U navedenoj studiji (Farrell \& Barnes, 1993) učestvovale su porodice koje su činili roditelji i deca u adolescentskom uzrastu. Ona je pokazala da se sa porastom kohezije u porodici, poboljšava psihološko funkcionisanje članova porodice, odnosno, više je samopoštovanje, a niže su: difuzija identiteta, depresivnost i anksioznost, prema ocenama svih članova porodice. Osim toga, viša kohezivnost podrazumevala je i veće slaganje između bračnih partnera, kao i pozitivnije ishode u ponašanju adolescenata - bolji školski uspeh, bolje vladanje u školi i niži nivo devijantnosti. Viši nivo kohezije bio je povezan i sa procenjenom boljom komunikacijom između članova, odnosno manjom zastupljenošću konflikata i većom otvorenošću. Kada se radi o adaptabilnosti, ona se nije pokazala u toj meri značajnom za ove ishode, ali dobijeni rezultati su uglavnom govorili u prilog linearnog odnosa. Tako su sa njenim porastom, majke izveštavale o svojoj nižoj depresivnosti, a očevi o višem samopoštovanju, manjoj difuziji identiteta, većoj otvorenosti u komunkaciji u porodici. Kada se radilo o adolescentima, ova dimenzija je bila važnija za devojčice nego dečake.

U studiji koja je za cilj imala ispitivanje odnosa između porodičnog funkcionisanja i tenzije u obavljanju porodičnih i poslovnih uloga, otkriveno je da sa porastom 
konflikata u porodici, raste ova vrsta pritiska kod majki, ali ne i kod očeva (Lee, Vernon-Feagans, Vazquez, \& Kolak, 2003). Sa porastom porodične kohezivnosti, smanjivala se doživljena tenzija, opet na poduzorku majki, ali ne i očeva. S druge strane, očevi koji su otvorenost i stepen organizovanosti i strukture u porodici ocenjivali višom, doživljavali su manje tenzije u obavljanju ovih uloga, dok se ove varijable nisu izdvojile kao značajne za doživljaj tenzije na poduzorku majki.

I druga istraživanja su pokazala da postojanje tenzije, neslaganja i stresa u odnosu sa članovima porodice (Carlson \& Perrewe, 1999; Fox \& Dwyer, 1999; Grzywacz \& Marks, 2000; Parasuraman \& Simmers, 2001), kao i slaba podrška porodice (Carlson \& Perrewe, 1999; Grzywacz \& Marks, 2000; Parasuraman \& Simmers, 2001) povećavaju doživljaj konflikta između posla i porodice. U jednoj od ovih studija (Carlson \& Perrewe, 1999), socijalna podrška se odnosila na procenu stepena u kome je ispitanik priznat i uvažavan od strane porodice. Osim toga, ona je uključivala i dostupnost povratne informacije i emocionalne podrške, kao i mogućnost podele zaduženja i odgovornosti u porodici. $\mathrm{Na}$ kraju, u okviru ove skale, od ispitanika se tražilo da procene kvalitet interpersonalnih odnosa sa partnerom, porodicom i prijateljima. Ova vrsta podrške ostvarila je indirektan efekat na doživljeni konflikt posla i porodice, direktno delujući na opažanje stresogenosti porodičnih uloga. U jednoj od pomenutih studija (Grzywacz \& Marks, 2000), na primer, pokazalo se da je podrška bračnog partnera smanjivala negativno prelivanje, a povećavala pozitivno prelivanje sa porodice na posao, dok ovi efekti nisu otkriveni kada se radilo o prelivanju u suprotnom smeru. Nekoliko studja je pokazalo da povećanjem zadovoljstva porodicom, opadaju negativno prelivanje i konflikt između posla i porodice (Frone, Russell, \& Cooper, 1994; Frone, Yardely, \& Markel, 1997). Sa povećanjem porodične kohezije povećavalo se i pozitivno prelivanje sa porodice na posao, dok veza sa negativnim prelivanjem nije utvrđena (Stevens, Minnotte, Mannon, \& Kiger, 2007).

Osim toga, konflikt posao-porodica (Carlson, 1999; Grzywacz \& Marks, 2000), kao i konflikt porodica-posao (Behson, 2002), bili su viši u onim porodicama u kojima su deca bila kod kuće. Takođe, doživljeni konflikt posao-porodica je bio veći u porodicama u kojima je bilo više dece, naročito mlađe dece, što se objašnjava količinom zahteva koji takva porodična struktura postavlja pred pojedinca, što slabi njegove resurse, te vodi intenzivnijem doživljavanju i jednog i drugog konflikta (Greenhaus \& Parasuraman, 1986; Zhang \& Liu, 2011). Istraživanja su pokazala da najviši nivo zahteva postavljaju bebe i deca predškolskog uzrasta i da konflikt posao-porodica opada sa povećanjem uzrasta deteta, te da je najniži u porodicama sa odraslom decom, koja ne žive sa roditeljima (npr. Allen \& Finkelstein, 2014; Osherson \& Dill, 1983).

\section{Kvalitet međuljudskih odnosa na poslu}

Radna organizacija, između ostalog, predstavlja i socijalni sistem, čiju glavnu komponentu čine kolege (Mesmer-Magnus \& Viswesvaran, 2009). Tako se podrška kolega izdvojila kao važan koping mehanizam koji zaposlenoj osobi omogućava 
da lakše uspostavi balans između zahteva porodice i posla. Postojanje podrške u organizaciji bilo je u negativnoj korelaciji sa konfliktom posao-porodica (Carlson \& Perrewe, 1999; Greenhaus, Bedeian, \& Mossholder, 1987; Grzywacz \& Marks, 2000). U ovim istraživanjima je odsustvo/prisustvo podrške operacionalizovano na različite načine. Na primer, u jednoj od tih studija (Greenhaus et al., 1987), ispitanici su procenjivali u kom stepenu su odnosi na poslu napeti, neprijateljski i nepoverljivi. Dakle, podrška se ogledala u proceni kvaliteta interpersonalnih odnosa. Pretpostavlja se da podrška dobijena od strane kolega ili šefa stvara pozitivnije radno okruženje, što situacije na poslu čini manje stresnim (Carlson \& Perrewe, 1999). Pomenuti autori su utvrdili da socijalna podrška ostvaruje efekat na doživljaj konflikta posao-porodica tako što smanjuje stresogenost uloge zaposlenog, koja je određena inkompatibilnim i nedovoljno jasnim zahtevima, kao i doživljajem preopterećenosti samom ulogom. U ovom istraživanju socijalna podrška je operacionalizovana preko skora na skali koja je brojala deset stavki, koje su odgovarale onima korišćenim za merenje socijalne podrške u porodici, opisane u prethodnom delu rada, i koje su uključivale i procenu kvaliteta odnosa sa kolegama, nadređenima i podređenima.

Takođe, kako su pokazala neka istraživanja (Tepper, 2000), hostilnost supervizora, definisano kao hostilna verbalna i neverbalna ponašanja, koja ne uključuju fizički kontakt, jeste važan prediktor konflikta posao-porodica. Postojanje mentora uopšte, opažena podrška od njega, kao i opažanje da mentor ima slične porodičnoprofesionalne vrednosti je povezano sa nižim konfliktom posao-porodica (Nielson, Carlson, \& Lankau, 2001). Jedna studija je pokazala da u slučaju slične poslovne situacije, intenzitet doživljenog konflikta zavisi od stepena podrške dobijene od strane supervizora (Goff, Mount, \& Jamison, 1990), koja podrazumeva njegovu spremnost da sa svojim zaposlenim diskutuje o porodičnim problemima i bude fleksibilan kada porodična situacija to zahteva.

Kako bi uloga kvaliteta međuljudskih odnosa na poslu u doživljavanju konflikta između posla i porodice bila jasnija, u ovom radu će se zasebno ispitivati efekti odnosa sa nadređenim i odnosa sa kolegama na poslu na doživljaj konflikta posaoporodica.

Antecedensi konflikata posao-porodica i porodica-posao bi mogli da se sumiraju kroz prikaz rezultata metaanalitičkih studija (Byron, 2005; Michel, Kotrba, Mitchelson, Clark, \& Baltes, 2011). U njoj je otkriveno da su varijable koje se tiču posla u intenzivnijoj korelaciji sa konfliktom posao-porodica, dok su konstrukti koji nisu u vezi sa poslom imali jači efekat na konflikt porodica-posao, iako to nije bilo tako dosledno kao u slučaju prve vrste konflikta. U njoj su potvrđeni efekti broja radnih sati i podrške od strane kolega i nadređenih na konflikt posao-porodica, pri čemu je ova vrsta podrške bila značajna i za konflikt porodica-posao, ali je taj efekat bio slabiji. Sa povećanjem podrške, opadali su doživljeni konflikti, dok je sa povećanjem broja radnih sati rastao i konflikt posao-porodica. Podrška porodice, sukobi u porodici, starost najmlađeg deteta su bili skoro jednako značajni za obe vrste konflikta, dok su stres u porodici i broj dece imali snažniji efekat na konflikt porodica-posao. Pored varijabli iz domena socijalnih odnosa, na kojima je fokus ovog rada, u analizi su statistički kontrolisani efekti sociodemografskih varijabli (broj sati rada, broj dece 
i starost najmlađeg deteta) koje su se u Bajronovoj studiji pokazale posebno značajnim za doživljaj konflikta.

Da sumiramo, osnovni cilj ovog rada je da ponudi odgovor na pitanje: da li su različiti aspekti porodičnog funkcionisanja i kvalitet interpersonalnih odnosa na poslu (sa kolegama i šefom), važni za doživljaj konflikta između posla i porodice kod osoba koje, pored uloge zaposlenog, imaju i uloge bračnog partnera i roditelja. U skladu sa tim, formulisan je i cilj istraživanja usmeren na ispitivanje doprinosa dimenzija porodičnog funkcionisanja (kohezivnosti, adaptabilnosti i komunikacije) i kvaliteta odnosa sa šefom i kolegama u predviđanju konflikta posao-porodica.

\section{Metod}

\section{Uzorak i procedura}

Ovo istraživanje predstavlja deo studije koja se bavi proučavanjem indikatora i modela usklađivanja poslovnih i porodičnih uloga (Hedrih, Todorović i Ristić, 2013), koja je sprovedena na teritoriji Republike Srbije. Uzimajući u obzir broj stanovnika iz poslednjeg popisa stanovništva za svaki okrug, dobijeni su podaci o procentualnom učešću populacije svakog okruga u ukupnoj populaciji Srbije. Na taj način uzorak je podeljen na administrativne okruge, te je studijom obuhvaćen geografsko klasterski uzorak od 2023 stanovnika Srbije. Za potrebe ovog rada korišćen je poduzorak od 644 zaposlena ispitanika koji su u braku, od čega je 375 (59.1\%) ženskog pola. Od ukupnog broja pomenutog poduzorka, $82(12.7 \%)$ ispitanika su preduzetnici, 237 (36.8\%) radi u državnom sektoru, $234(36.3 \%)$ je zaposleno u privatnim firmama, dok je 23 (3.6\%) neprijavljeno, a 68 (10.6\%) obavlja privremene poslove ili radi više poslova.

\section{Instrumenti}

PORPOS baterija (Hedrih i sar., 2013) predstavlja instrument sačinjen od 389 stavki (marker pitanja) grupisanih u određeni broj kraćih skala, koje su namenski odabrane za potrebe projekta 179002. Za procenu dimenzija porodičnog funkcionisanja Olsonovog modela (Olson, 2011), korišćene su stavke preuzete iz skala FACES III (Family Adaptability \& Cohesion Scales; Olson et al., 1985) i FACES IV (Family Adaptability \& Cohesion Evaluation Scales, VERSION IV; Olson, 2011). Kohezivnost je operacionalizovana preko 7 stavki (npr. „Članovi naše porodice vole da provode vreme zajedno”), Adaptabilnost uključuje 6 stavki (npr. „U našoj porodici svako je spreman da preuzme obaveze drugog člana"), dok je Komunikacija određena uz pomoć 3 ajtema (npr. „Članovi porodice mogu jedni s drugima mirno da razgovaraju o problemima"). U ovom istraživanju pomenute skale su pokazale zadovoljavajuću pouzdanost merenja (Kohezivnost $\alpha=.88$; Adaptabilnost $\alpha=.71$ i Komunikacija $\alpha=$ .85). U cilju operacionalizacije konflikta porodica-posao i konflikta posao-porodica korišćena je Skala za procenu konflikta posla sa porodicom (6 ajtema; npr. „Zahtevi mog posla ometaju moj porodični život"), kao i Skala za procenu konflikta porodice sa 
poslom (4 ajtema; „Dešava se da zbog obaveza kod kuće ne uspem da završim svoje obaveze na poslu") (Hedrih i sar., 2013). Vrednost koeficijenta interne konzistenci ( $\alpha$ $=.70$ ) ukazuje na nisku pouzdanost merenja pomenutog konflikta posao-porodica na poduzorku ovog istraživanja. Drugopomenuta skala nema zadovoljavajuću pouzdanost merenja ( $\alpha=.18$ ), te je to razlog neuključivanja konflikta porodica-posao kao jedne od kriterijumskih varijabli. Kratka skala za ispitivanje međuljudskih odnosa na poslu korišćena je za procenu odnosa sa kolegama (4 ajtema; $\alpha=.73$ ), kao i za procenu odnosa sa pretpostavljenim (2 ajtema; $\alpha=$.65) (Hedrih i sar., 2013).

\section{Rezultati}

\section{Deskriptivni pokazatelji i interkorelacije osnovnih varijabli istraživanja}

Na uzorku ovog istraživanja broj radnih sati u toku dana kreće se u rasponu od 2 do $16(\mathrm{M}=8.47$; $\mathrm{SD}=1.91)$, broj dece u porodici od 0 do $9(\mathrm{M}=1.80 ; \mathrm{SD}=.75)$, dok je uzrast najmlađeg deteta predstavljen rasponom vrednosti od 4 meseca do 45 godina $(\mathrm{M}=12.65 ; \mathrm{SD}=8.56)$.

Deskriptivni podaci mera dimenzija porodičnog funkcionisanja (kohezivnost, adaptabilnost i komunikacija), interpersonalnih odnosa na poslu (odnosi sa kolegama i odnosi sa pretpostavljenim) i konflikta posao-porodica, pokazuju da su svi podaci u opsegu normalne distribucije (skjunis i kurtozis +/- 1) (Tabela 1).

Tabela 1

Deskriptivni pokazatelji vrednosti osnovnih varijabli istraživanja

\begin{tabular}{lccccccc}
\hline & $N$ & Min & Max & $M$ & $S D$ & $S k$ & $K u$ \\
\hline Porodično funkcionisanje & & & & & & & \\
Kohezivnost & 640 & 1.00 & 5.00 & 4.05 & .63 & -.658 & .831 \\
Adaptabilnost & 640 & 1.00 & 5.00 & 3.22 & .55 & .057 & .603 \\
Komunikacija & 638 & 1.00 & 5.00 & 4.13 & .73 & -.759 & .655 \\
\hline Odnosi na poslu & & & & & & & \\
Odnosi sa kolegama & 605 & 1.00 & 5.00 & 3.82 & .78 & -.664 & .271 \\
Odnosi sa pretpostavljenim & 553 & 1.00 & 5.00 & 3.92 & .88 & -.888 & .946 \\
\hline Konflikt posao-porodica & 592 & 1.00 & 5.00 & 2.30 & .93 & .563 & -.244 \\
\hline
\end{tabular}

Napomena. Sk-Skjunis (koeficijent asimetrije); $K u$ - Kurtozis (koeficijent izduženosti).

Rezultati korelacione analize (Tabela 2) ukazuju na postojanje značajnih povezanosti između dimenzija porodičnog funkcionisanja, kvaliteta interpesonalnih odnosa na poslu i konflikta posao-porodica. Iako je povezanost između kohezivnosti i komunikacije visoka $\mathrm{r}=.71(\mathrm{p}<.001)$, sve preostale značajne korelacije su niskog $\mathrm{i}$ umerenog intenziteta $($ od $\mathrm{r}=.13(\mathrm{p}<.01)$ do $\mathrm{r}=.54 ;(\mathrm{p}<.001))$, te ne bi trebalo govoriti o prisustvu multikolinearnosti, što bi narušavalo primenu multiple regresione analize (videti Tabelu 4). 
Tabela 2

Interkorelacije između osnovnih varijabli istraživanja (Pirsonov koeficijent linearne korelacije)

\begin{tabular}{lccccc}
\hline & Kohezivnost & Adaptabilnost & Komunikacija & $\begin{array}{c}\text { Odnosi sa } \\
\text { kolegama }\end{array}$ & $\begin{array}{c}\text { Odnosi sa } \\
\text { pretpostavljenim }\end{array}$ \\
\hline $\begin{array}{l}\text { Kohezivnost } \\
\text { Adaptabilnost }\end{array}$ & $.45^{* * *}$ & & & & \\
$\begin{array}{l}\text { Komunikacija } \\
\text { Odnosi sa }\end{array}$ & $.71^{* * *}$ & $.40^{* * *}$ & & & \\
$\begin{array}{l}\text { kolegama } \\
\begin{array}{l}\text { Odnosi sa } \\
\text { pretpostavljenim }\end{array}\end{array}$ & $.24^{* * *}$ & .06 & $.25^{* * *}$ & & \\
$\begin{array}{l}\text { Konflikt posao- } \\
\text { porodica }\end{array}$ & $-.17^{* * *}$ & .03 & $.18^{* * *}$ & $.54^{* * *}$ & \\
\hline
\end{tabular}

$* * * p<.001 ; * * p<.01$.

\section{Predikcija konflikta posao-porodica na osnovu dimenzija porodičnog funkcionisanja i kvaliteta interpersonalnih odnosa na poslu}

Imajući u vidu rezultate Bajronove metaanalitičke studije (Byron, 2005) o važnosti broja radnih sati (u toku dana), broja dece i starosti najmlađeg deteta za doživljaj konflikta posao-porodica, sporovedena je multipla regresiona analiza u cilju provere važnosti navedenih varijabli za izraženost konflikta posao-porodica (Tabela 3).

Tabela 3

Važnost broja radnih sati, broja dece u porodici $i$ starosti najmladeg deteta za predikciju konflikta posao-porodica

\begin{tabular}{cllc}
\hline Model & Prediktori & Sažetak modela & Nezavisni doprinosi prediktora \\
\hline \multirow{2}{*}{1} & Broj radnih sati & & $\beta=.309 ; p<.001$ \\
& Broj dece u porodici & $R=.337 ; R^{2}=.114 ;$ & $\beta=-.063 ; p=.114$ \\
& Strarost najmlađeg deteta & & $\beta=-.159 ; p<.001$ \\
\hline
\end{tabular}

Kao što se može videti iz prikazane tabele, za doživljaj konflikta posao-porodica značajnim se izdvajaju broj radnih sati u toku dana, kao i uzrast najmlađeg deteta. Drugim rečima, što duže radimo u toku dana i što je uzrast najmlađeg deteta niži, izraženiji je konflikt posao-porodica. Iako su pomenute varijable značajne za predikciju navedene vrste konflikta, broj radnih sati u toku dana ima veći nezavisni doprinos u predikciji konflikta posao-porodica. Ceo model objašnjava 33.7\% varijanse kriterijuma.

Rukovodeći se ovim nalazima, a imajući u vidu osnovni cilj istraživanja (utvrđivanje relacija između dimenzija porodičnog funkcionisanja, kvaliteta interpersonalnih odnosa na poslu i konflikta posao-porodica), naredni korak u statističkoj analizi podataka bio je utvrđivanje nezavisnog doprinosa varijabli iz porodičnog i 
poslovnog konteksta za predikciju konflikta posao-porodica, ali uz kontrolu doprinosa broja radnih sati u toku dana i uzrasta najmlađeg deteta. Kako bi se kontrolisao doprinos pomenutih varijabli, iz varijable konflikt posao-porodica statistički je otklonjen deo koji je objašnjen brojem radnih sati i uzrastom najmlađeg deteta (snimljene su rezidualne vrednosti), te je tako formirana varijabla ubačena kao kriterijum u hijerarhijskoj regresionoj analizi. Rezultati su prikazani u Tabeli 4.

Tabela 4

Važnost dimenzija porodičnog funkcionisanja i kvaliteta interpersonalnih odnosa za predikciju konflikta posao-porodica (Hijerarhijska regresiona analiza)

\begin{tabular}{|c|c|c|c|c|c|c|}
\hline Model & Prediktori & Sažetak mod & ela & $\begin{array}{c}\text { Nezavisni doprinosi } \\
\text { prediktora }\end{array}$ & Tolerance & VIF \\
\hline \multirow{3}{*}{1} & Kohezivnost & \multirow{3}{*}{$\begin{array}{l}R=.206 ; R^{2}=.043 \\
F(3,539)=6.06\end{array}$} & \multirow{3}{*}{$p<.001$} & $\beta=-.059 ; p=.354$ & .447 & 2.239 \\
\hline & Adaptabilnost & & & $\beta=.067 ; p=.157$ & .790 & 1.266 \\
\hline & Komunikacija & & & $\beta=-.180 ; p<.01$ & .465 & 2.149 \\
\hline \multirow{5}{*}{2} & Kohezivnost & \multirow{3}{*}{$\begin{array}{l}R=.309 ; R^{2}=.095 \\
F(5,539)=11.25\end{array}$} & \multirow{4}{*}{$p<.001$} & $\beta=-.038 ; p=.538$ & .443 & 2.258 \\
\hline & Adaptabilnost & & & $\beta=.050 ; p=.281$ & .786 & 1.272 \\
\hline & Komunikacija & & & $\beta=-.122 ; p<.05$ & .452 & 2.214 \\
\hline & $\begin{array}{l}\text { Odnosi sa } \\
\text { kolegama }\end{array}$ & \multirow{2}{*}{$\begin{array}{l}\text { Promena u } R^{2}=.053 \\
\mathrm{~F}_{\text {change }(2,534)}=15.57 * * *\end{array}$} & & $\beta=-.170 ; p<.001$ & .673 & 1.486 \\
\hline & $\begin{array}{l}\text { Odnosi sa } \\
\text { pretpostavljenim }\end{array}$ & & $p<.001$ & $\beta=-.101 ; p<.05$ & .710 & 1.408 \\
\hline
\end{tabular}

Napomena. Tolerance i VIF - parametri procene multikolinearnosti

Najpre, može se uočiti da na osnovu vrednosti parametara procene multikolinearnosti (Tolerance i $\mathrm{VIF}^{4}$ ) nije narušena pretpostavka o multikolineranosti, te ne postoji prepreka za sprovođenje ove vrste analize.

Kao što se može videti, oba prediktivna modela su statistički značajna. Komunikacija predstavlja jedini statistički značajan prediktor konflikta posao-porodica iz domena porodičnog funkcionisanja. Prvi model objašnjava svega $4.3 \%$ varijanse kriterijuma, što predstavlja nizak doprinos u predikciji. Nakon uvođenja varijabli iz sfere interpersonalnih odnosa na poslu procenat objašnjene varijanse konflikta posao-porodica se povećava za 5.3\% i ta promena je statistički značajna. Ako se uzme u obzir drugi model, on objašnjava ukupno 9.5\% varijanse kriterijuma, što i dalje predstvalja nizak doprinos predikciji. U drugom koraku analize najveći nezavisni doprinos u predikciji kriterijuma ostvaruje varijabla odnosi sa kolegama, zatim komunikacija i na kraju odnosi sa pretpostavljenim. Svi pomenuti prediktori su u negativnoj korelaciji sa konfliktom posao-porodica. Drugim rečima, što je kvalitet komunikacije između članova porodice niži, kao i kvalitet interpersonanih odnosa na poslu, konflikt posao-porodica je izraženiji, što je u skladu sa očekivanjima. Bitno je uočiti da se standardizovani regresioni koeficijent (ß) komunikacije kao prediktora

\footnotetext{
${ }^{4}$ Ukoliko je VIF veći od 10 to može ukazivati na problem multikolinearnosti (Bowerman \& O’Connell, 1990; Myers, 1990; prema Field, 2009); Takođe, o problemu multikolinearnosti može se govoriti ukoliko je Tolerance ispod 0.10 , odnosno Tolerance ispod 0.20 ukazuje na potencijalni problem multikolinearnosti (Menard, 1995; prema Field, 2009).
} 
smanjuje, kao i njegova statistička značajnost, nakon uvođenja odnosa sa kolegama i odnosa sa šefom. Pritom, poslednje navedene varijable imaju značajan nezavisan doprinos u predikciji konflikta posao-porodica.

Ovaj nalaz je poslužio kao osnova za sprovođenje medijacione analize korišćenjem postupka koji su predložili Preacher i Hayes (Preacher \& Hayes, 2008). Pri tome, komunikacija je tretirana kao prediktor, odnosi sa kolegama i odnosi sa pretpostavljenim kao medijatori, a konflikt posao-porodica kao kriterijumska varijabla.

\section{Analiza medijacije}

Rezultati medijacione analize kojom su testirani posrednički efekti varijabli iz domena kvaliteta interpersonalnih odnosa na poslu (odnosi sa kolegama i odnosi sa pretpostavljenim) na odnos između komunikacije i konflikta posao-porodica prikazani su u Tabeli 5.

Tabela 5

Totalni, direktni i indirektni efekti odnosa sa kolegama i odnosa sa pretpostavljenim na odnos između komunikacije i konflikta posao-porodica

\begin{tabular}{llccccccc}
\hline Prediktor & Medijatori & $a$ & $b$ & $c$ & $c^{\prime}$ & $a b$ & $L L C I$ & $U L C I$ \\
\hline \multirow{2}{*}{ Komunikacija } & $\begin{array}{l}\text { Odnosi sa } \\
\text { kolegama }\end{array}$ & $.30^{* * *}$ & $-.26^{* * *}$ & $-.26^{* * *}$ & $-.18^{* *}$ & -.077 & -.1179 & -.0458 \\
\cline { 2 - 8 } & $\begin{array}{l}\text { Odnosi sa } \\
\text { pretpostavljenim }\end{array}$ & $.25 * * *$ & $-.28^{* * *}$ & $-.25^{* * *}$ & $-.18^{* * *}$ & -.069 & -.1153 & -.0385 \\
\hline
\end{tabular}

Napomena. $a$ - efekat prediktora na medijator, $b$ - efekat medijatora na kriterijum, $c$ - totalni efekat prediktora na kriterijum, $c^{\prime}$ - direktan efekat prediktora na kriterijum kada se pretpostavljeni medijator drži pod kontrolom, $a b$ - indirektni efekat, odnosno efekat medijatora u relaciji između prediktora i kriterijuma, $L L C I$ - donja granica intervala poverenja, $U L C I-$ gornja granica intervala $* * * p<.001 ; * * p<.01$.

Na osnovu prikazanih rezultata može se videti da se veza između komunikacije i konflikta posao-porodica ostvaruje delimično direktno, a delimično je posredovana kvalitetom odnosa sa kolegama, odnosno kvalitetom odnosa sa pretpostavljenim. Dakle, može se zaključiti da je medijacija u oba slučaja delimična. Preciznije rečeno, kvalitet komunikacije u porodici je pozitivno povezan sa kvalitetom interpersonalnih odnosa na poslu (odnosi sa kolegama i sa pretpostavljenim), što doprinosi smanjenom doživljaju konflikta na relaciji posao-porodica.

\section{Diskusija i zaključak}

Cilj ovog rada bio je utvrđivanje značaja koji bi različite forme interpersonalnih odnosa mogle da imaju za doživljaj konflikta između posla i porodice kod zasposlenih roditelja, koji su u braku. Krenulo se od pretpostavke da i u jednoj i 
u drugoj sferi pojedinac ostvaruje socijalne odnose, koji mogu biti manje ili više funkcionalni, i koji bi, u zavisnosti od toga, mogli da otežaju ili olakšaju usklađivanje poslovnih i porodičnih uloga (npr. Carlson \& Perrewe, 1999; Fox \& Dwyer, 1999; Greenhaus et al., 1987; Grzywacz \& Marks, 2000; Parasuraman \& Simmers, 2001). Kako provera pouzdanosti skale nije omogućila ispitivanje efekata varijabli iz domena porodičnog funkcionisanja i kvaliteta interpersonalnih odnosa na poslu na doživljeni konflikt porodica-posao, u analizu je kao kriterijum uključen samo doživljaj konflikta posao-porodica, odnosno opažanje osobe da njena porodica trpi usled poslovnih obaveza.

Rezultati ovog rada su pokazali da varijable iz pomenutih domena objašnjavaju vrlo mali procenat varijanse ovog kriterijuma. Pritom, kada se radi o domenu porodičnih odnosa, samo se komunikacija izdvojila kao značajan prediktor konflikta posaoporodica. S druge strane, obe vrste odnosa iz poslovnog okruženja jesu ostvarile značajan doprinos u predikciji ovog tipa konflikta, objašnjavajući 5\% varijanse kriterijuma. Ako uzmemo u obzir rezultate metaanalitičkih studija (Byron, 2005; Michel et al., 2011), prema kojima su varijable iz domena posla, u poređenju sa onim iz domena porodice, značajnije za konflikt posao-porodica, ovakvi podaci su očekivani. Pojedinci koji kvalitet komunikacije u svojoj porodici procenjuju višim, doživljavaju manji konflikt između poslovnih i porodičnih zahteva, odnosno, procenjuju da poslovne obaveze u manjoj meri ugrožavaju obavljanje porodičnih zadataka. Takođe, ovaj konflikt procenjuju manjim one osobe koje odnose sa kolegama i pretpostavljenim opažaju boljim.

Sa uvođenjem interpersonalnih odnosa na poslu u model, značaj komunikacije u porodici za predviđanje konflikta je opao, što je poslužilo kao osnova za pretpostavku o postojanju složenije strukture odnosa između ovih varijabli. Preciznije, naša pretpostavka je bila da bi varijable iz domena posla mogle imati direktni efekat na doživljaj konflikta između posla i porodice, dok bi komunikacija svoj efekat ostvarivala indirektno, preko odnosa sa kolegama i nadređenim. Ova hipoteza bi mogla da nađe podršku i u već navedenim podacima o većem značaju varijabli iz poslovne sfere za ovu vrstu konflikta (Byron, 2005). Rezultati su ovakav odnos delimično potvrdili. Komunikacija ostvaruje delom direktan, delom indirektan efekat na konflikt posao-porodica. Što pojedinac boljim ocenjuje komunikaciju u porodici, to kvalitetnijim procenjuje i odnose na poslu, a to se odražava i na doživljeni konflikt između posla i porodice, koji se doživljava manjim.

Dakle, pojedinci koji procenjuju da u njihovoj porodici postoji spremnost na pažljivo slušanje, otvaranje i deljenje osećanja, uz međusobno poštovanje i saosećanje, izveštavaju o manje izraženom konfliktu između posla i porodice. Ovo bi moglo da se objasni podrškom koju pojedinac, u ovakvoj atmosferi, dobija od članova svoje porodice. Zahtevi koji dolaze iz domena posla nisu ugrožavajući po njihovo funkcionisanje jer porodica sa razvijenim komunikacionim veštinama jeste spremnija na empatiju, pružanje podrške i efikasno rešavanje problema (Olson, 2000), te tako i onih problema koji bi mogli da proizađu iz sukoba uloga. Ovo je u skladu sa rezultatima studija koje su pokazale da odsustvo tenzije, kao i visoko slaganje i podrška članova porodice (Carlson \& Perrewe, 1999; Grzywacz \& Marks, 2000; Parasuraman \& Simmers, 2001), smanjuju doživljaj konflikta između poslovnih i porodičnih 
uloga, tako što redukuju stresnost u obavljanju porodičnih uloga.

Kada se radi o odnosima sa kolegama i pretpostavljenim, što su ovi odnosi bolji, to je konflikt posao-porodica manji. Prema nekim autorima (Mesmer-Magnus \& Viswesvaran, 2009), podrška kolega je mehanizam koji zaposlenoj osobi omogućava da na efikasniji način uspostavi ravnotežu između poslovnih i porodičnih obaveza. Značaj podrške u organizaciji za doživljaj konflikta posao-porodica potvrdila su i druga istraživanja (Carlson \& Perrewe, 1999; Greenhaus et al., 1987; Grzywacz \& Marks, 2000). U jednoj od tih studija (Carlson \& Perrewe, 1999) utvrđeno je da ova vrsta podrške taj efekat ostvaruje umanjivanjem stresnosti uloge zaposlenog.

Otkriveni medijatorski efekat komunikacije na konflikt posla i porodice, ostvaren preko interpersonalnih odnosa na poslu, bi mogao da se interpretira na dva načina. S jedne strane, moguće je da podržavajuće porodično okruženje, koje porodicu čini funkcionalnijom, ima ulogu zaštitnog faktora za zaposlenog pojedinca. Podrška i razumevanje koje pružaju članovi porodice smanjuju stresnost u obavljanju porodičnih uloga (Carlson \& Perrewe, 1999), ostavljajući tako osobi dovoljno resursa za uspostavljanje i održavanje pozitivnih odnosa sa kolegama i pretpostavljenim, što olakšava i suočavanje sa izazovima na poslu, umanjujući time i doživljeni konflikt. $\mathrm{S}$ druge strane, u izgradnji takve komunikacione strukture u porodici učestvuje i on sam, sa svojim komunikacionim veštinama. Ako se pretpostavi da su njegove komunikacione veštine na visokom nivou, onda ih on koristi i u interakciji sa kolegama, ostvarujući time kvalitetne odnose sa njima, koji, na ranije opisan način, smanjuju konflikt između poslovnih i porodičnih uloga.

Ono što je donekle neočekivan nalaz ovog istraživanja jeste da se, preostale dve dimenzije porodičnog funkcionisanja (kohezivnost i adaptabilnost), ne izdvajaju kao značajni prediktori doživljaja konflikta posao-porodica. Imajući u vidu da se funkcionalnost porodice može definisati uz pomoć sve tri dimenzije porodičnog funkcionisanja, pretpostavka je da zaposleni roditelji koji žive i rade u Srbiji, svoju snagu za prevazilaženje problema s kojima se suočavaju na poslu „obezbeđuju” iz porodičnog okruženja koje se, u svim ili bar u većini aspekata, može okarakterisati kao adekvatno. To bi značilo da porodica pored dobre komunikacije između članova, poseduje i druge kvalitete, kao što su kvalitetni emocionalni odnosi i funkcionalna organizacija poslova i raspodela uloga, što bi zaposlenom roditelju olakšavalo suočavanje sa stresom na poslu. Osim toga, mali procenat objašnjene varijanse konflikta posao-porodica može ukazivati na kompleksnost samog fenomena, odnosno na njegovu multifaktorsku uslovljenost. Stoga, preporuka za naredna istraživanja ide u pravcu prepoznavanja i uključivanja drugih relevantnih faktora u predikciji konflikata koji se tiču odnosa posao-porodica, kao i odnosa porodica-posao, a sve u cilju obuhvatnijeg proučavanja i objašnjenja pomenutog fenomena.

Iako se prednost ovog istraživanja ogleda u korišćenju velikog i geografskog klasterskog uzorka, treba napomenuti da to ujedno može predstavljati i slabost jer se pri tome povećava „efekat zdravog radnika” (Popov, Latovljev i Nedić, 2015). Ovaj efekat je dobio naziv po tome što su u većini ovakvih istraživanja ispitanici bili radnici koji su ispitivani u vreme kada su bili na poslu. Pretpostavka je da su to relativno zdrave osobe, $\mathrm{tj}$. osobe koje ne pate od posledica prekomerne stresnosti konflikta 
posao-porodica (npr. simptoma izgaranja), dok se očekuje da su oni koji su ugrožena kategorija odsutni sa posla zbog bolesti, onesposobljenosti ili stresa na radu. Prema tome, trebalo bi u narednim istraživanjima uključiti i zaposlene koji zbog različitih posledica stresnosti konflikata uloga nisu na poslu. To bi predstavljalo dragoceni izvor podataka, koji bi mogao ponuditi drugačije nalaze i njihovu interpretaciju, a sve u cilju obuhvatnijeg razumevanja fenomena koji se odnosi na sukob uloga u različitim životnim sferama.

Generalno, nalazi ovog istraživanja sugerišu da treba jačati porodične resurse, kao i kvalitet interpersonalnih odnosa na poslu, a u cilju ovladavanja različitim izazovima koji proizlaze iz konflikta na relaciji posao-porodica (i porodica-posao).

\section{Reference}

Allen, T. D., \& Finkelstein, L. M. (2014). Work-family conflict among members of fulltime dual-earner couples: An examination of family life stage, gender, and age. Journal of occupational health psychology, 19(3), 376-384.

Behson, S. J. (2002). Coping with family-to-work conflict: The role of informal work accommodations to family. Journal of Occupational Health Psychology, 7(4), 324 341.

Boyraz, G., \& Sayger, T. V. (2011). Psychological well-being among fathers of children with and without disabilities: The role of family cohesion, adaptability, and paternal self-Efficacy. American journal of men's health, 5(4), 286-296.

Byron, K. (2005). A meta-analytic review of work-family conflict and its antecedents. Journal of Vocational Behavior, 67(2), 169-198.

Carlson, D. S. (1999). Personality and role variables as predictors of three forms of workfamily conflict. Journal of Vocational Behavior, 55(2), 236-253.

Carlson, D. S., \& Perrewé, P. L. (1999). The role of social support in the stressor-strain relationship: An examination of work-family conflict. Journal of Management, 25(4), 513-540.

Farrell, M. P., \& Barnes, G. M. (1993). Family Systems and Social Support: A Test of the Effects of Cohesion and Adaptability on the Functioning of Parents and Adolescents. Journal of Marriage and the Family, 55(1), 119-132.

Field. A. (2009). Discovering statistics using SPSS (3rd Edition). London: SAGE Publications Ltd.

Fox, M. L., \& Dwyer, D. J. (1999). An investigation of the effects of time and involvement in the relationship between stressors and work-family conflict. Journal of Occupational Health Psychology, 4(2), 164-174.

Frone, M. R., Russell, M., \& Cooper, M. L. (1994). Relationship between job and family satisfaction: Causal or noncausal covariation? Journal of Management, 20(3), 565-579.

Frone, M. R., Yardley, J. K., \& Markel, K. S. (1997). Developing and testing an integrative model of the work-family interface. Journal of Vocational Behavior, 50(2), 145-167.

Goff, S. J., Mount, M. K., \& Jamison, R. L. (1990). Employer supported child care, work- 
family, and absenteeism: A field study. Personnel Psychology, 43(4), 793-809.

Greenhaus, J. H., Bedeian, A. G., \& Mossholder, K. W. (1987). Work experiences, job performance, and feelings of personal and family well-being. Journal of Vocational Behavior, 31(2), 200-215.

Greenhaus, J. \& Beutell, N. (1985). Sources and conflict between work and family roles. Academy of Management Review, 10(1), 76-88.

Greenhaus, J. H., \& Parasuraman, S. (1986). A work-nonwork interactive perspective of stress and its consequences. Journal of Organizational Behavior Management, 8(2), 37-60.

Grzywacz, J. G., \& Marks, N. F. (2000). Reconceptualizing the work-family interface: An ecological perspective on the correlates of positive and negative spillover between work and family. Journal of Occupational Health Psychology, 5(1), 111-126.

Hedrih, V. (2013). Posao i porodica: dosadašnja istraživanja, teorijski pristupi i shvatanja. U V. Hedrih, J. Todorović i M. Ristić (Ur.), Odnosi na poslu i u porodici u Srbiji početkom 21. veka (str. 9-18). Niš: Filozofski fakultet.

Hedrih, V., Todorović, J. i Ristić, M. (Ur.). (2013). Odnosi na poslu i u porodici u Srbiji početkom 21. veka. Niš: Filozofski fakultet, Srbija.

Lee, M., Vernon-Feagans, L., Vazquez, A., \& Kolak, A. (2003). The influence of family environment and child temperament on work/family role strain for mothers and fathers. Infant and Child Development: An International Journal of Research and Practice, 12(5), 421-439.

Mesmer-Magnus, J., \& Viswesvaran, C. (2009). The role of the coworker in reducing work-family conflict: A review and directions for future research. Pratiques Psychologiques, 15(2), 213-224.

Michel, J. S., Kotrba, L. M., Mitchelson, J. K., Clark, M. A., \& Baltes, B. B. (2011). Antecedents of work-family conflict: A meta-analytic review. Journal of organizational behavior, 32(5), 689-725.

Netemeyer, R. G., Boles, J. S., \& McMurrian, R. (1996). Development and validation of work-family conflict and family-work conflict scales. Journal of Applied Psychology, 81(4), 400-410.

Nielson, T. R., Carlson, D. S., \& Lankau, M. J. (2001). The supportive mentor as a means of reducing work-family conflict. Journal of Vocational Behavior, 59(3), 364-381.

Olson, D. H. (2000). Circumplex model of marital and family systems. Journal of Family Therapy, 22(2), 144-167.

Olson, D. H. (2011). FACES IV and the Circumplex Model: Validation Study. Journal of Marital and Family Therapy, 37(1), 64-80.

Olson, D. H., Portner, J., \& Bell, R. (1982). Family adaptability and cohesion evaluation scales. In D. H. Olson et al. (Eds.), Family inventories: Inventories used in a national survey of families across the family life cycle (pp. 5-24). St. Paul, MN: University of Minnesota, Department of Family Social Science.

Olson, D. H., Portner, J., \& Lavee, Y. (1985). Faces III: Family Adaptability \& Cohesion Evaluation Scales. St. Paul, MN: University of Minnesota, Department of Family Social Science. 
Osherson, S., \& Dill, D. (1983). Varying Work and Family Choices: Their Impact on Men's Work Satisfaction. Journal of Marriage and Family, 45(2), 339-346.

Parasuraman, S., \& Simmers, C. A. (2001). Type of employment, work-family conflict and well-being: A comparative study. Journal of Organizational Behavior, 22(5), 551-568.

Popov, S., Latovljev, M., i Nedić, A. (2015). Sindrom izgaranja kod zdravstvenih i prosvetnih radnika: Uloga situacionih i individualnih faktora. Psihološka istraživanja, 18(1), 5-22.

Preacher, K. J., \& Hayes, A. F. (2008). Asymptotic and resampling strategies for assessing and comparing indirect effects in multiple mediator models. Behavior Research Methods, 40(3), 879-891.

Rot, N. (2008). Osnovi socijalne psihologije. Beograd: Zavod za udžbenike.

Stevens, D. P., Minnotte, K. L., Mannon, S. E., \& Kiger, G. (2007). Examining the "Neglected Side of the Work-Family Interface": Antecedents of Positive and Negative Family-to-Work Spillover. Journal of Family Issues, 28(2), 242-262.

Tepper, B. J. (2000). Consequences of abusive supervision. Academy of Management Journal, 43(2), 178-190.

Vandeleur, C. L., Perrez, M., \& Schoebi, D. (2007). Associations between measures of emotion and familial dynamics in normative families with adolescents. Swiss Journal of Psychology, 66(1), 5-16.

Zedeck, S. (1987). Work, Family, and Organizations: An Untapped Research Triangle. Institute of Industrial Relations. Institute for Research on Labor and Employment Working Paper Series. Paper iirwps-010-87. Unversity of California, Berkeley.

Zhang, J. \& Liu, Y. (2011). Antecedents of Work-Family Conflict: Review and Prospect. International Journal of Business and Management, 6(1), 89-103.

\title{
Marija Pejičićs \\ Kristina Ranđelović \\ University of Niš, \\ Faculty of Philosophy, \\ Department of Psychology, \\ Niš, Serbia
}

\section{THE ROLE OF FAMILY FUNCTIONING AND INTERPERSONAL RELATIONS AT WORK IN WORK-FAMILY CONFLICT}

\begin{abstract}
The aim of this paper was to examine the effects of the dimensions of family functioning and relationships with colleagues and with the superior at work on the experience
\end{abstract}

\footnotetext{
${ }^{5}$ Corresponding author email: marija.pejicic@filfak.ni.ac.rs
} 
of work-family conflict in the employed married parents. We applied the appropriate scales of PORPOS battery, constructed for the purpose of the project 179002 (aimed to examine the diversity of relationships at work and in the family in Serbia in 2011) in the sample of 644 respondents of both genders (59.1\% females). For the assessment of the dimensions of family functioning, the items were taken from both FACES III and FACES IV, while the other variables (work-family conflict and interpersonal relations at work) were examined with scales constructed within the project. Among the dimensions of family functioning, only communication distinguished itself as a significant predictor, while both types of relationships at work (with colleagues and the superior) predicted the experience of the work-family conflict. With the increase in the perceived quality of these relationships, as well as with better perceived family communication, the conflict was reduced. In addition, it had been found that the effect of communication on work-family conflict was partly mediated by the relationships at work. The higher the quality of family communication was, the better the quality of work-related relationships, and the lower the work-family conflict. Despite the low percentage of variance explained, the obtained results justified the assumed contribution of interpersonal relationships at work and in the family to the prediction of the coordination of work and family roles.

Keywords: work-family conflict, family functioning, relationship with colleagues, relationship with the superior

Primljeno: 30. 06. 2019.

Primljena korekcija: 18.10. 2019.

Prihvaćeno za objavljivanje: 22. 10. 2019. 